\title{
Nitrogen, phosphorus, potassium, calcium and magnesium release from two compressed fertilizers: column experiments
}

\author{
M. J. Fernández-Sanjurjo, E. Alvarez-Rodríguez, A. Núñez-Delgado, M. L. Fernández-Marcos, and A. Romar-Gasalla \\ Dept. Edafoloxía e Química Agrícola (Soil Sci. and Agric. Chem.), Engineering Polytechnic School, Universidade de \\ Santiago de Compostela, Campus Univ. s/n, 27002 Lugo, Spain
}

Correspondence to: A. Núñez-Delgado (avelino.nunez@usc.es)

Received: 23 June 2014 - Published in Solid Earth Discuss.: 9 July 2014

Revised: 26 November 2014 - Accepted: 27 November 2014 - Published: 21 December 2014

\begin{abstract}
The objective of this work was to study nutrients release from two compressed nitrogen-potassiumphosphorous (NPK) fertilizers. In the Lourizán Forest Center, tablet-type controlled-release fertilizers (CRF) were prepared by compressing various mixtures of fertilizers without covers or binders. We used soil columns $(50 \mathrm{~cm}$ long and $7.3 \mathrm{~cm}$ inner diameter) that were filled with soil from the surface layer $(0-20 \mathrm{~cm})$ of an A horizon corresponding to a Cambic Umbrisol. Tablets of two slow-release NPK fertilizers (11-18-11 or 8-8-16) were placed into the soil (within the first $3 \mathrm{~cm}$ ), and then water was percolated through the columns in a saturated regime for 80 days. Percolates were analyzed for $\mathrm{N}, \mathrm{P}, \mathrm{K}^{+}, \mathrm{Ca}^{2+}$ and $\mathrm{Mg}^{2+}$. These elements were also determined in soil and fertilizer tablets at the end of the trials. Nutrient concentrations were high in the first leachates and reached a steady state when $1426 \mathrm{~mm}$ of water had been percolated, which is equivalent to approximately 1.5 years of rainfall in this geographic area. In the whole trial, both tablets lost more than $80 \%$ of their initial N, P and K contents. However, $\mathrm{K}^{+}, \mathrm{Ca}^{2+}$ and $\mathrm{Mg}^{2+}$ were the most leached, whereas $\mathrm{N}$ and $\mathrm{P}$ were lost in leachates to a lesser extent. Nutrient release was slower from the tablet with a composition of 8-8-16 than from the 11-18-11 fertilizer. In view of that, the 8-8-16 tablet can be considered more adequate for crops with a nutrient demand sustained over time. At the end of the trial, the effects of these fertilizers on soil chemical parameters were still evident, with a significant increase of $\mathrm{pH}$, available $\mathrm{Ca}^{2+}, \mathrm{Mg}^{2+}, \mathrm{K}^{+}, \mathrm{P}$ and effective cation exchange capacity (eCEC) in the fertilized columns, as well as a significant decrease in exchangeable $\mathrm{Al}^{3+}$, reaching values $<0.08 \mathrm{cmol}(+) \mathrm{kg}^{-1}$.
\end{abstract}

\section{Introduction}

Conventional fertilizers supply plants quickly with nutrients, giving rise immediately to high nutrient availability. In some cases, this rapid contribution may be excessive, and nutrient excess, as well as nutrient deficiency, can have deleterious effects on plant growth. Moreover, nutrient excess may cause them to be transferred to surface and ground water, resulting in environmental problems (Khan et al., 2014). Therefore, a sound management of fertilization should reconcile the maintenance of high crop yields with reduced costs, resource economy and environmental issues.

Controlled-release fertilizers (CRF) may represent a solution to these problems. The behavior of CRF is close to that of an ideal fertilizer, since theoretically the release of nutrients takes place in the moment and the amount required by plants (Oertli, 1980; Jiménez-Gómez, 1992). JiménezGómez (1992) and Shaviv (2001) classified CRF according to the mechanism of delaying nutrient transfer to the substrate: materials coated by polymers or resins, low-solubility organic substances (urea-formaldehyde, isobutylen diurea) or nutrients in a carrier matrix (waxes, peat, vermiculite, lignin, etc.). Most trials conducted to test the effectiveness of these fertilizers concluded that the amount of nutrients required is significantly reduced compared to conventional fertilizers, highlighting the energy savings and the improved use of N, minimizing its losses (Shoji and Kanno, 1994; Shaviv, 2001, 2001; Hangs et al., 2003; Chen et al., 2008; Sato and Morgan, 2008; Entry and Sojka, 2008; Hyatt et al., 2010; Wilson et al., 2010). Another reason for recommending the use of $\mathrm{CRF}$ is to prevent the emission of $\mathrm{N}_{2} \mathrm{O}$ from $\mathrm{N}$ fertilization practices, due to its role in climate change (Cheng et al., 2006; Jingyan et al., 2010). However, the effectiveness 
Table 1. Chemical characteristics of the soil used in this study (average of three replicates, with standard deviation in parentheses).

\begin{tabular}{rrrrrrrrrr}
\hline $\mathrm{pH}$ & $\mathrm{C}$ & $\mathrm{N}-\mathrm{NO}_{3}^{-}$ & $\mathrm{N}-\mathrm{NH}_{4}^{+}$ & $\mathrm{P}$ & $\mathrm{K}$ & $\mathrm{Ca}$ & $\mathrm{Mg}$ & $\mathrm{Al}$ & eCEC \\
\hline 4.13 & 19.20 & 45.51 & 187.11 & 8.96 & 0.24 & 0.11 & 0.13 & 0.92 & 1.40 \\
$(0.04)$ & $(2.30)$ & $(1.60)$ & $(7.90)$ & $(0.80)$ & $(0.06)$ & $(0.04)$ & $(0.03)$ & $(0.13)$ & $(0.11)$ \\
\hline
\end{tabular}

$\mathrm{C}$ : total $\mathrm{C}\left(\mathrm{g} \mathrm{kg}^{-1}\right) ; \mathrm{N}-\mathrm{NO}_{3}^{-}$and $\mathrm{N}-\mathrm{NH}_{4}^{+}\left(\mathrm{mg} \mathrm{kg}^{-1}\right) ; \mathrm{P}$ : available $\mathrm{P}\left(\mathrm{mg} \mathrm{kg}^{-1}\right) ; \mathrm{K}, \mathrm{Ca}, \mathrm{Mg}$, Al: exchangeable cations $\left(\mathrm{cmol}(+) \mathrm{kg}^{-1}\right)$; eCEC: effective cation exchange capacity $\left(\mathrm{cmol}(+) \mathrm{kg}^{-1}\right)$.

Table 2. Initial tablet weights ( $\mathrm{g}$ ) and $\mathrm{N}, \mathrm{P}, \mathrm{K}, \mathrm{Mg}$ and $\mathrm{Ca}$ amounts (g) applied to each column with the treatments (average of three replicates, with standard deviation in parentheses).

\begin{tabular}{lrrrrrr}
\hline Treatment & $\begin{array}{r}\text { Initial } \\
\text { weight }\end{array}$ & $\mathrm{N}$ & $\mathrm{P}$ & $\mathrm{K}$ & $\mathrm{Mg}$ & $\mathrm{Ca}$ \\
\hline $11-18-11$ & 30.83 & 5.29 & 2.68 & 2.50 & 0.29 & 1.79 \\
& $(0.18)$ & $(0.20)$ & $(0.15)$ & $(0.12)$ & $(0.01)$ & $(0.27)$ \\
$8-8-16$ & 38.03 & 5.04 & 1.74 & 4.49 & 2.89 & 1.27 \\
& $(0.27)$ & $(0.40)$ & $(0.06)$ & $(0.04)$ & $(0.09)$ & $(0.09)$ \\
\hline
\end{tabular}

of this type of fertilizer has not been extensively tested under a range of environmental conditions that may occur due to climatic variation and soil water content.

In Galicia (NW Spain), some studies were conducted in forest plots using tablet-type controlled-release fertilizers, produced in the Lourizán Forest Center (Pontevedra) by compressing various mixtures of fertilizers without covers or binders. They were nitrogen-potassium-phosphorous (NPK) fertilizers (11-18-11 and 8-8-16) formulated to promote growth of forest trees. The results indicated that, compared to conventional fertilizers, these CRF increased the height, diameter and survival rate of Eucaliptus globulus and Pinus pinaster, whereas no significant differences were observed in $P$. radiata (Bará and Morales, 1977). However, these studies are limited and focused on the effects on forest production, thus needing further research to test the behavior of such CRF and to investigate the dynamics of each nutrient release.

The objectives of this work are (1) to study the dynamics of nutrient release by two different controlled-release fertilizers prepared by compression, without covers or binders, assessing the rate of release of the tablets and the losses suffered by leaching, and (2) to study the impact on the chemical characteristics of an acid forest soil and the drainage waters generated. For that purpose a laboratory experiment was conducted under controlled conditions using soil columns.

\section{Materials and methods}

\subsection{Soil used}

The experiment was conducted on an acid sandy loam soil developed over granite, collected in an abandoned field with typical vegetation of scrub (Ulex spp., Erica spp., Cytisus spp.). This soil has low pH (4.13), available $P\left(8.9 \mathrm{mg} \mathrm{kg}^{-1}\right)$ and effective cation exchange capacity (eCEC) $\left(1.4 \mathrm{cmol}(+) \mathrm{kg}^{-1}\right)$, and is classified as Cambic Umbrisol (humic) (IUSS-WRB, 2007). Table 1 shows its main chemical characteristics. The surface soil layer (0$20 \mathrm{~cm}$ ) was collected after removing the vegetation and the litter. The soil was oven-dried at $40^{\circ} \mathrm{C}$ and sieved through a $5 \mathrm{~mm}$ mesh prior to introduction in laboratory columns $(50 \mathrm{~cm}$ long and $7.3 \mathrm{~cm}$ inner diameter).

\subsection{Fertilizer tablets}

One NPK compressed tablet, having an 11-18-11 or 8-8-16 composition (which are appropriate formulations for forest fertilization), was placed in each soil column. Calcium phosphate, potassium sulfate, $\mathrm{N}$ as amide, and urea-formaldehyde and magnesite (magnesium carbonate) were used in the manufacture of the tablets. The size of these tablets was $3.3 \mathrm{~mm}$ in diameter and $33.0 \mathrm{~mm}$ in thickness. Table 2 shows the weight and nutrient contents of the fertilizer tablets.

\subsection{Laboratory columns}

The experimental design consisted of three replicates per treatment, including controls. The experimental device was described by Núñez-Delgado et al. (1997) and has been used in previous studies (Núñez-Delgado et al., 2002; PousadaFerradás et al., 2012). A soil sample ( $900 \mathrm{~g})$ was introduced in each column, tapping the column to facilitate the settlement of the particles and to achieve a bulk density similar to that of natural soil. Finally, the effective soil depth was $20 \mathrm{~cm}$, and bulk density was $1.075 \mathrm{~g} \mathrm{~cm}^{-3}$. The experiment was conducted under saturation conditions, in order to avoid variability in moisture content and at the same time ensuring water-saturation conditions, and thus ruling out the influence of redox processes. This procedure was carried out in previous soil column studies (Núñez-Delgado et al., 1997, 2002; Pousada-Ferradás et al., 2012), always bearing in mind that the results of this kind of experiment cannot be extrapolated to aerated conditions.

After filling the columns, the soils were saturated with distilled water from the bottom by capillarity, to facilitate the removal of pore air and to guarantee wetting. When the wetting was completed, the soils were weighed to determine the water content at saturation. Then, distilled water started to flow continuously through the columns from the top, by gravity, 


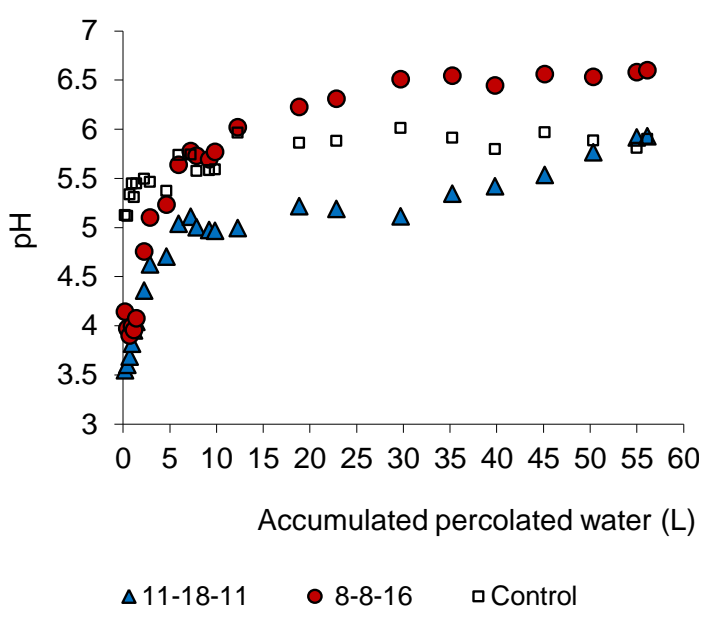

Figure 1. Acidity $(\mathrm{pH})$ of leachates from fertilized and control columns as a function of the volume of percolated water (average of three replicates).

using the constant level device and the complementary apparatus described in Núñez-Delgado et al. (1997). The flow rate and the $\mathrm{pH}$ and electrical conductivity (EC) of the leachates were measured in each sample for 18 days. By this time, the EC was stabilized at around $9 \mu \mathrm{Scm}^{-1}$, and one fertilizer tablet was placed in each column (except for controls) and introduced in the upper part of the soil (within the first $3 \mathrm{~cm}$ ). The water flow was resumed and, on average, six leachate samples were collected daily from each column for 15 days, preserving it at $4{ }^{\circ} \mathrm{C}$. We selected six samples/day based in previous trials, in view of the variability of some parameters that were evaluated and in the final volume reached. Each of the six samples were equivalent to $0.117 \mathrm{~L}$ in volume. The $\mathrm{pH}$ and EC were measured in freshly collected samples; when values for these parameters were very similar in successive samples, the sampling frequency was reduced to once a day. At the end of the columns experiment, the flow of distilled water was stopped, the samples corresponding to each day were mixed and homogenized and an aliquot was reserved for analysis. The whole period of water flow was 80 days and the total water flow was $56.15 \mathrm{~L}$. At the end of the experiment, the remainder of each tablet was collected and analyzed.

\subsection{Chemical analysis}

The following determinations were performed in leachates: $\mathrm{pH}$ and $\mathrm{EC}$ (potentiometric methods), concentrations of $\mathrm{NH}_{4}^{+}$and $\mathrm{NO}_{3}^{-}$(by steam distillation, after adding $\mathrm{MgO}$ and Devarda's alloy) (Bremmer, 1965), $\mathrm{P}$ (by visible spectrophotometry; Olsen and Sommers, 1982), $\mathrm{Ca}^{2+}, \mathrm{Mg}^{2+}$ and $\mathrm{K}^{+}$(by atomic absorption or emission spectrometry, PerkinElmer AAnalyst 200).

Soil samples before and at the end of the experiment were subjected to the following determinations: $\mathrm{pH}$ in wa-

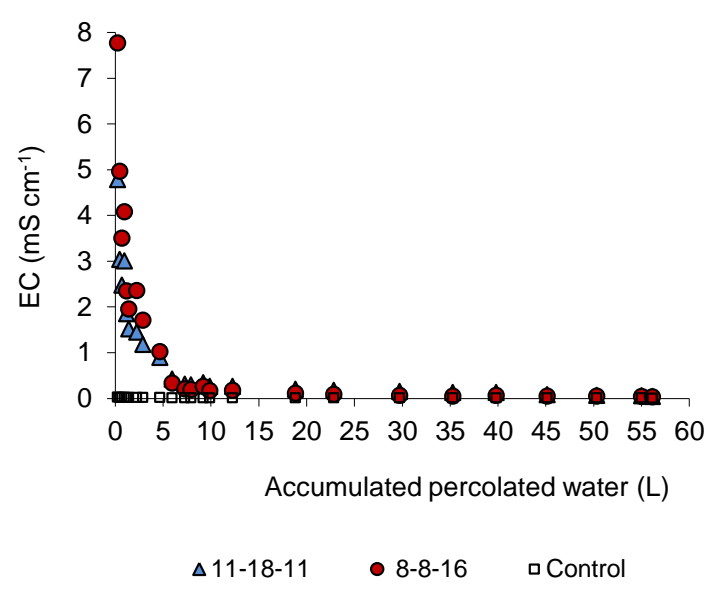

Figure 2. EC of leachates from fertilized and control columns as a function of the volume of percolated water (average of three replicates).

ter (soil: water ratio $1: 10$ ), total carbon and nitrogen (using a LECO 2000 auto analyzer), exchangeable $\mathrm{Ca}^{2+}, \mathrm{Mg}^{2+}$, $\mathrm{Na}^{+}, \mathrm{K}^{+}, \mathrm{Al}^{3+}$ (extracted by $1 \mathrm{M} \mathrm{NH}_{4} \mathrm{Cl}-$ Peech et al., 1947 - and measured by a PerkinElmer AAnalyst 200 atomic absorption spectrometer) and available phosphorus (Olsen and Sommers, 1982). The effective cation exchange capacity was calculated as the sum of $\mathrm{Ca}^{2+}, \mathrm{Mg}^{2+}, \mathrm{Na}^{+}, \mathrm{K}^{+}$and $\mathrm{Al}^{3+}$, extracted by $1 \mathrm{M} \mathrm{NH}_{4} \mathrm{Cl}$. $\mathrm{NO}_{3}^{-}$and $\mathrm{NH}_{4}^{+}$were extracted by $2 \mathrm{M}$ $\mathrm{KCl}$ (Keeney and Nelson, 1982) and determined by steam distillation (Bremmer, 1965).

\subsection{Statistical analysis}

Data were statistically treated by means of SPSS 19.0 for Windows (IBM Corp. Armonk, NY, 2010). Analysis of variance was performed, determining the least significant differences, and using Kolmogorov-Smirnov to tests for normality.

\section{Results and discussion}

\subsection{Chemical characteristics of leachates}

\subsection{1 pH}

At the beginning of the experiment, all leachates from fertilized columns had $\mathrm{pH}$ values significantly lower than the controls $(p<0.001)$ (Fig. 1). After the percolation of the first $5.97 \mathrm{~L}$, leachates from fertilized columns experienced a rapid $\mathrm{pH}$ increase. The $\mathrm{pH}$ value of leachates from treatment 8-8-16 exceeded that of the control when $4.67 \mathrm{~L}$ of percolated water (equivalent to $1116 \mathrm{~L} \mathrm{~m}^{-2}$ ) had been collected. In this treatment (8-8-16), $\mathrm{pH}$ values ranged between 3.90 and 6.60. On the contrary, leachates from treatment 11-18-11 had $\mathrm{pH}$ levels significantly lower than that of the controls until the last sampling date, when both $\mathrm{pH}$ values were similar. 
The initial acidity of leachates from fertilized columns can be attributed to the displacement of acidic exchange cations from soil by cations released by fertilizers (Núñez-Delgado et al., 1997, 2002).

\subsubsection{Electrical conductivity}

Figure 2 shows the time-course evolution of EC in the leachates. Regarding the 8-8-16 treatment, EC reached a value near $8 \mathrm{mS} \mathrm{cm}^{-1}$ after percolating $0.24 \mathrm{~L}$, then rapidly decreasing, reaching values $<4 \mathrm{mS} \mathrm{cm}^{-1}$ (threshold for saline soils) when $0.48 \mathrm{~L}$ were percolated and finally dropped to $0.034 \mathrm{mS} \mathrm{cm}^{-1}$ at the end of the experiment. With regard to the 11-18-11 treatment, EC values were below $4 \mathrm{mS} \mathrm{cm}^{-1}$ from $0.24 \mathrm{~L}$ percolation, then progressively decreasing to 0.042 , at the end. Control columns showed an initial EC value of 0.021 , being $0.003 \mathrm{mS} \mathrm{cm}^{-1}$ at the end of the experiment.

\subsubsection{Ammonium, Nitrate and Phosphorus}

High amounts of ammonium were leached from fertilized columns in the first 5 days of water flow, after the percolation of $5.97 \mathrm{~L}$ (Fig. 3), representing around $70 \%$ of the total ammonium leachate at the end of the experiment in both tablets. Although most $\mathrm{NH}_{4}^{+}$was leached during the first days, this loss corresponded to a high volume of percolated water, concretely the amount of water collected during the first 5 days of flow $(5.97 \mathrm{~L})$ is equivalent to 1.5 years of rainfall in the area $\left(1426 \mathrm{~L} \mathrm{~m}^{-2}\right)$. It must be kept in mind that percolation takes place in a saturation regime, so that the prevalence of this reduced form of nitrogen is favored. Another factor that may influence the forms of $\mathrm{N}$ that are leached is the type of surface charge of soil colloids. Xiong et al. (2010), in an experiment with soil columns, found greater leaching of $\mathrm{NH}_{4}^{+}$ than of $\mathrm{NO}_{3}^{-}$in soils with variable charge, contrary to the results obtained in soils with permanent charge. The soils in our study have mineral composition similar to that of Xiong et al. (2010) (hydroxy-Al interlayered vermiculites, kaolinites; data not shown) and high organic matter content, therefore with variable charge also prevailing. These results can be due to the presence of positive surface charge on some variable-charge compounds when $\mathrm{pH}$ value is acid or subacid, then making it difficult for the cations to be adsorbed into the soil, whereas dominate negative charges in soils having a permanent charge are an advantage to cations being retained. Other studies with fertilized soil columns (NúñezDelgado et al., 2002) also indicate high leaching of $\mathrm{NH}_{4}^{+}$. After this initial period, ammonium concentrations were similar in leachates from fertilized and unfertilized columns. The accumulated ammonium loss showed similar trends in both fertilized treatments, but surprisingly it was higher in treatment $8-8-16$ than in $11-18-11$ (Fig. 3).

The nitrate concentration in leachates from fertilized columns was high in the first day of flow $(1.44 \mathrm{~L})$, but de- a)

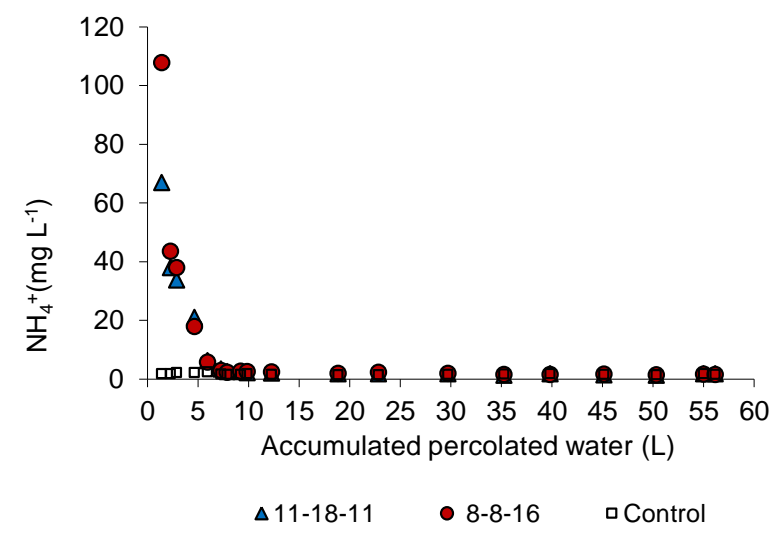

b)

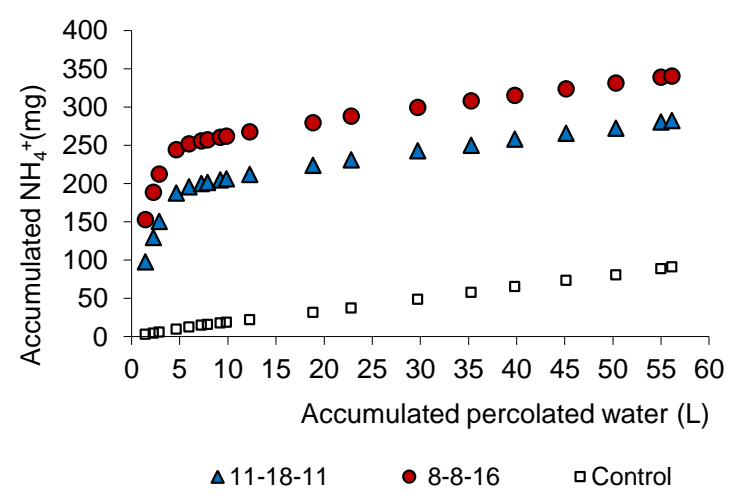

Figure 3. Ammonium concentrations in leachates (a) and accumulated $\mathrm{NH}_{4}^{+}$losses (b) from fertilized and control columns along the experiment (average of three replicates).

creased sharply in the second day (2.27 L) (Fig. 4). From the fifth day $(5.97 \mathrm{~L}$ flow), nitrate concentrations were very similar in leachates from fertilized and control columns. Accumulated nitrate losses were also not significantly different between fertilized and control columns, suggesting that leached nitrate comes largely from the soil rather than from fertilizer tablets, probably because the nitrogen is supplied as amides and urea, and the medium is inadequate for the formation of nitrates. The loss of nitrogen as nitrate is slightly lower than the loss of ammonium nitrogen in the fertilized columns, which is not surprising taking into account the reducing conditions during the experiment. Alva (2006) reported considerably lower $\mathrm{NH}_{4}^{+}$than $\mathrm{NO}_{3}^{-}$leaching from leaching columns fertilized with urea or manure in sandy soils, but under non-reducing conditions. Other studies using leaching columns also report a high initial leaching of $\mathrm{NH}_{4}^{+}$and $\mathrm{NO}_{3}^{-}$and the subsequent decrease of these losses (Sato and Morgan, 2008).

The phosphorus concentration was very low in leachates from control columns (Fig. 5), in accordance with the low concentration of available P in these soils (Table 3), 
Table 3. Soil physicochemical properties at the end of the incubation in soils under the different treatments (average of three replicates, with standard deviation in parentheses).

\begin{tabular}{|c|c|c|c|}
\hline & Control & $11-18-11$ & $8-8-16$ \\
\hline $\mathrm{pH}$ & $\begin{array}{l}4.92^{\mathrm{a}} \\
(0.08)\end{array}$ & $\begin{array}{l}5.70^{\mathrm{b}} \\
(0.16)\end{array}$ & $\begin{array}{l}6.19^{b} \\
(0.09)\end{array}$ \\
\hline $\mathrm{C}\left(\mathrm{g} \mathrm{kg}^{-1}\right)$ & $\begin{array}{r}17.1^{\mathrm{a}} \\
(1.84)\end{array}$ & $\begin{array}{r}16.6^{\mathrm{a}} \\
(2.34)\end{array}$ & $\begin{array}{r}16.8^{\mathrm{a}} \\
(1.16)\end{array}$ \\
\hline $\mathrm{NH}_{4}^{+}\left(\mathrm{mg} \mathrm{kg}^{-1}\right)$ & $\begin{array}{l}44.0^{\mathrm{a}} \\
(3.40)\end{array}$ & $\begin{array}{r}51.9^{a} \\
(15.1)\end{array}$ & $\begin{array}{r}58.7^{\mathrm{a}} \\
(6.38)\end{array}$ \\
\hline $\mathrm{NO}_{3}^{-}\left(\mathrm{mg} \mathrm{kg}^{-1}\right)$ & $\begin{array}{r}174.8^{\mathrm{a}} \\
(11.6)\end{array}$ & $\begin{array}{r}170.9^{a} \\
(21.7)\end{array}$ & $\begin{array}{r}194.2^{\mathrm{a}} \\
(22.1)\end{array}$ \\
\hline Available P $\left(\mathrm{mg} \mathrm{kg}^{-1}\right)$ & $\begin{array}{r}17.7^{\mathrm{a}} \\
(1.95)\end{array}$ & $\begin{array}{r}113.4^{\mathrm{b}} \\
(8.17)\end{array}$ & $\begin{array}{l}86.4^{b} \\
(15.5)\end{array}$ \\
\hline $\begin{array}{l}\text { Exchangeable } \mathrm{K}^{+} \\
\left(\mathrm{cmol}(+) \mathrm{kg}^{-1}\right)\end{array}$ & $(0.02)$ & $0.31^{\mathrm{ab}}$ & $\begin{array}{l}1.03^{\mathrm{b}} \\
(0.90)\end{array}$ \\
\hline $\begin{array}{l}\text { Exchangeable } \mathrm{Ca}^{+2} \\
\left(\mathrm{cmol}(+) \mathrm{kg}^{-1}\right)\end{array}$ & $\begin{array}{l}0.21^{\mathrm{a}} \\
(0.04)\end{array}$ & $5.50^{\mathrm{c}}$ & $\begin{array}{l}1.86^{\mathrm{b}} \\
(0.50)\end{array}$ \\
\hline $\begin{array}{l}\text { Exchangeable } \mathrm{Mg}^{+2} \\
\left(\mathrm{cmol}(+) \mathrm{kg}^{-1}\right)\end{array}$ & $0.11^{\mathrm{a}}$ & $0.33^{\mathrm{a}}$ & $4.24^{b}$ \\
\hline $\begin{array}{l}\text { Exchangeable } \mathrm{Al}^{+3} \\
\left(\mathrm{cmol}(+) \mathrm{kg}^{-1}\right)\end{array}$ & $0.80^{\mathrm{b}}$ & $0.08^{\mathrm{a}}$ & $0.01^{\mathrm{a}}$ \\
\hline $\begin{array}{l}\text { Effective CEC } \\
\left(\mathrm{cmol}(+) \mathrm{kg}^{-1}\right)\end{array}$ & $1.27^{\mathrm{a}}$ & $(0.14)$ & $\begin{array}{l}7.20^{\mathrm{b}} \\
(0.90)\end{array}$ \\
\hline
\end{tabular}

* Different letters indicate significant differences $(p<0.001) . \Delta$ soil: increase of the amounts of $\mathrm{N}\left(\mathrm{N}-\mathrm{NO}_{3}^{-}+\mathrm{NH}_{4}^{+}\right)$, available $\mathrm{P}$ and exchangeable cations in the fertilized soil columns. a)

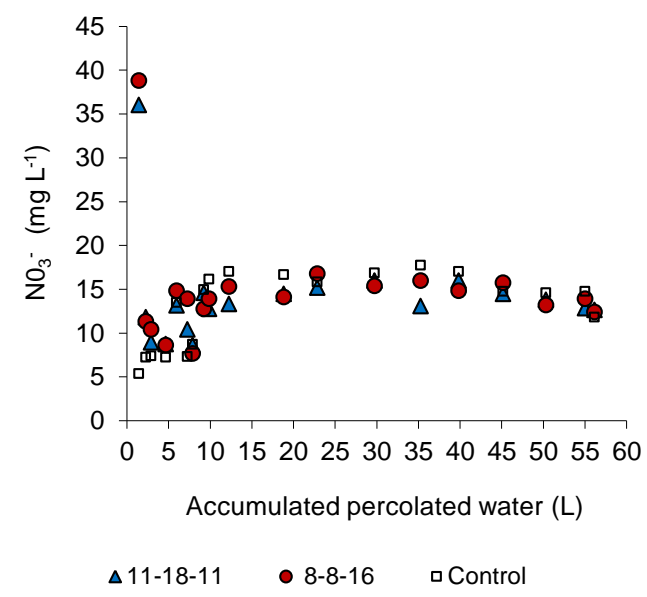

b)

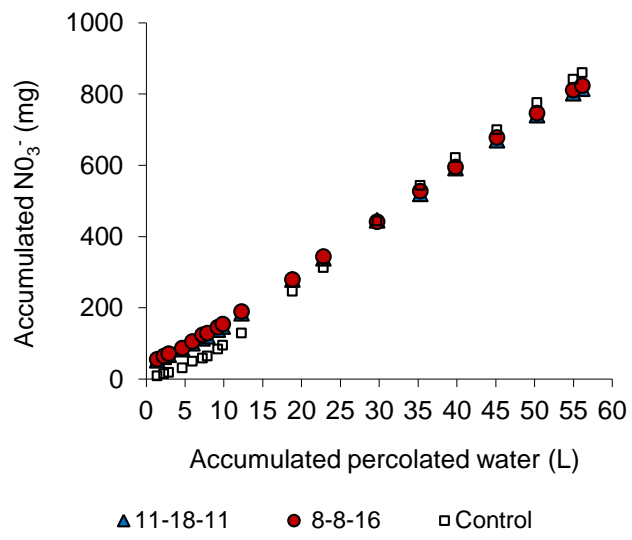

Figure 4. Nitrate concentrations in leachates (a) and accumulated $\mathrm{NO}_{3}^{-}$losses (b) from fertilized and control columns along the experiment (average of three replicates).

other elements, after an initial decrease, $\mathrm{Ca}^{2+}$ concentrations in leachates from this treatment increased again from $7.28 \mathrm{~L}$ percolation, and remained higher than those in the controls throughout the trial. Despite the Ca contents in tablet 8-816 not being much lower than in 11-18-11 (Table 2), $\mathrm{Ca}^{2+}$ concentrations in leachates in treatment 8-8-16 were higher than in the controls only in the first 4 days of leaching $(4.67 \mathrm{~L}$ percolation); from then on, the values were similar to those of the control columns and significantly lower $(p<0.005)$ than in treatment 11-8-11. This means that, at the end of the experiment, even after $56 \mathrm{~L}$ of water has flowed, the $8-8-16$ tablet still had high Ca content. At the end of the experiment, the $\mathrm{Ca}^{2+}$ accumulated in leachates was about 20 times higher in treatment 11-18-11 compared to that in treatment 8-8-16.

Magnesium leaching was similar in both fertilizer treatments (without significant differences), especially at the beginning of the experiment (Fig. 8). As was the case for other elements, the greatest loss corresponded to a leachate volume of $5.97 \mathrm{~L}\left(1426 \mathrm{~L} \mathrm{~m}^{-2}\right)$. From the tenth day $(12.28 \mathrm{~L}$ percolation), $\mathrm{Mg}^{2+}$ leaching was negligible in treatment $11-18-11$, 
a)

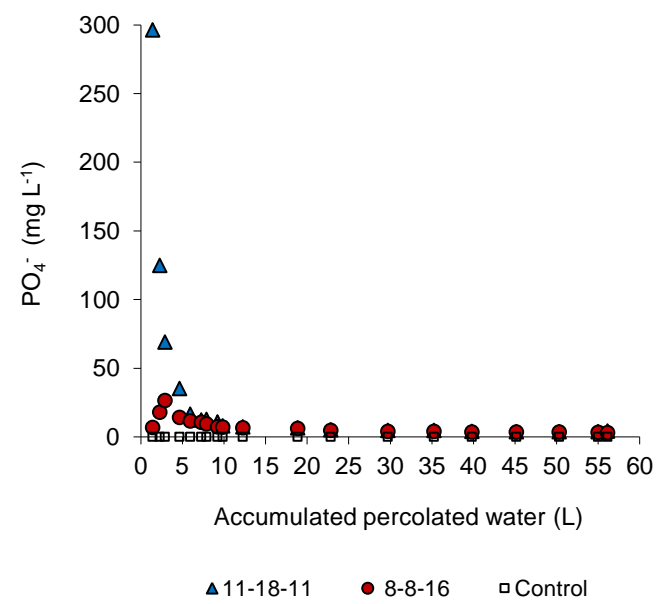

b)

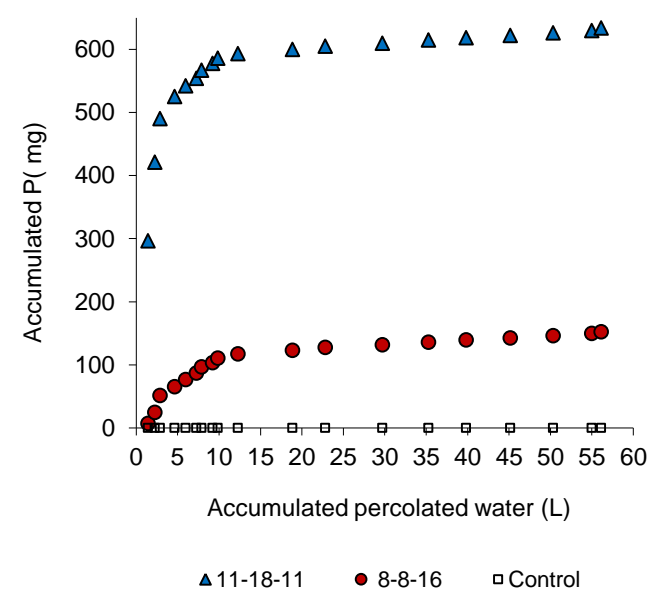

Figure 5. Phosphorus concentrations in leachates (a) and accumulated P losses (b) from fertilized and control columns along the experiment (average of three replicates).

but continued until the end of the experiment in treatment 8 8-16 (Fig. 8), in agreement with the greater $\mathrm{Mg}^{2+}$ content of this tablet (Table 2).

The differences between the two treatments regarding the amount and type of the elements that have been leached may be related to the quantity released by each treatment, as well as the different solubility of the compounds that form the tablets.

\subsection{Change of soil parameters after percolation}

At the end of the experiment, $\mathrm{pH}$ value was slightly higher in control columns than that found in the initial soil, which could result from alkalizing reactions occurring in the reducing conditions prevailing. Meanwhile, $\mathrm{pH}$ value was clearly higher in fertilized columns (Table 3). In fertilized columns, cations released by fertilizers may replace acid exchange cations, which would result in soil alkalization. This seems a)

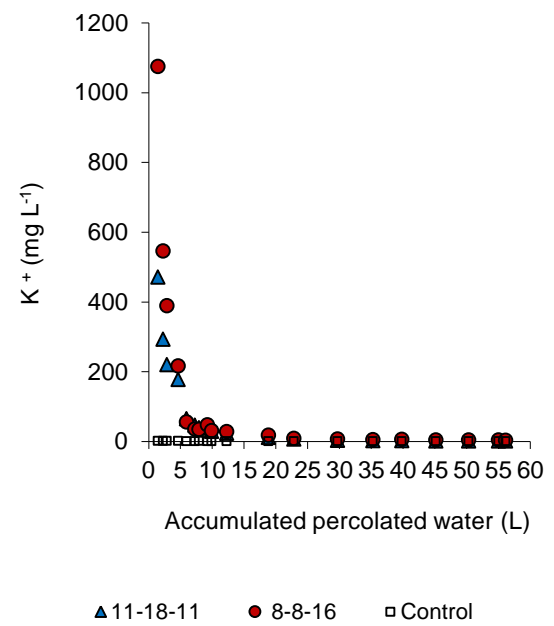

b)

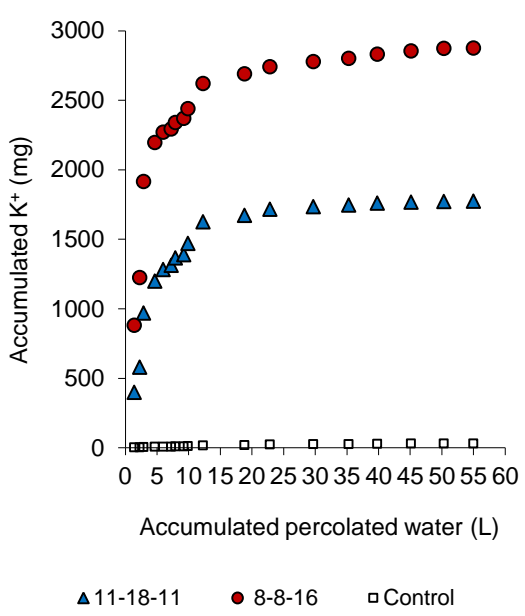

Figure 6. Potassium concentrations in leachates (a) and accumulated $\mathrm{K}^{+}$losses (b) from fertilized and control columns along the experiment (average of three replicates).

to be particularly remarkable in treatment $8-8-16$, which is richer in $\mathrm{K}^{+}$and $\mathrm{Mg}^{2+}$; also, leachates from this treatment, except for the initial period, had higher $\mathrm{pH}$ values than those from treatment 11-18-11 (Fig. 1). The initial acidification showed by the leachates could be in relation to the presence of acid cations that had been substituted by other cations provided by the fertilizers. The carbon concentration in soil decreased slightly after the experiment in all columns (Tables 2 and 3).

Ammonium concentrations in soil at the final stage were higher in the fertilized columns, particularly in treatment 8-8-16 (compared to control columns), but the differences were not significant. These results were comparable to ammonium concentrations in leachates. Apparently, treatment 8-8-16 released more ammonium than treatment 11-1811 . With regard to nitrate, no significant differences were observed between columns. Nitrogen released by fertilizers 
a)

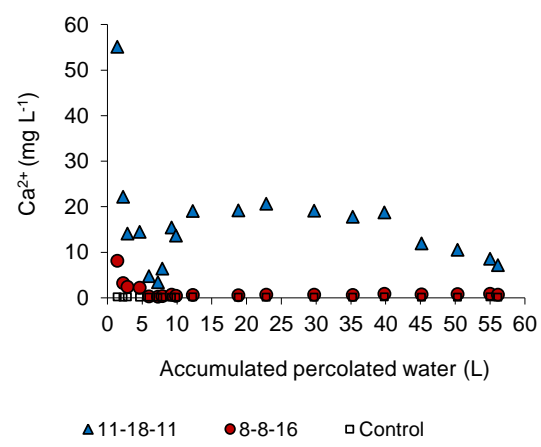

b)

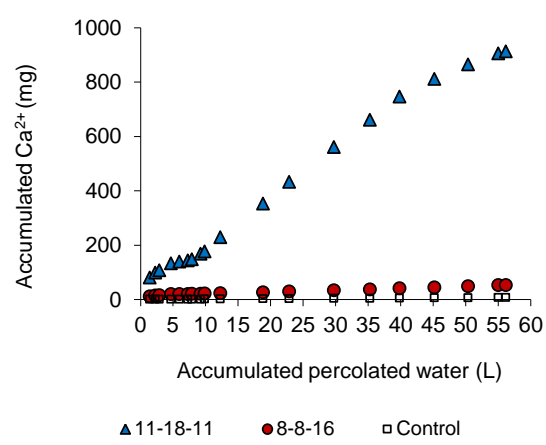

Figure 7. Calcium concentrations in leachates (a) and accumulated $\mathrm{Ca}^{2+}$ losses (b) from fertilized and control columns along the experiment (average of three replicates).

may have been leached as ammonium, or, more likely, lost through de-nitrification processes, taking into account the reducing conditions prevailing during the experiment (NúñezDelgado et al., 1997), or immobilized in microbial biomass.

Unlike nitrogen, final available phosphorus concentrations in fertilized soil columns were notably higher than in control columns, particularly in treatment 11-18-11, which provided more $\mathrm{P}$ (Table 2). These results are in agreement with the limited measured $\mathrm{P}$ leaching and may be related to the recognized low mobility of this element in soils, and particularly in acid soils (Gil-Sotres and Dieaz-Fierros, 1982; Garcia-Rodeja and Gil-Sotres, 1997).

As for the exchange cations, the concentrations of $\mathrm{Ca}^{2+}$, $\mathrm{Mg}^{2+}$ and $\mathrm{K}^{+}$increased in the fertilized columns (Table 3). Calcium was significantly higher in the fertilized columns than in the control columns, whereas the 11-18-11 treatment caused clearly higher values than that of the 8-8-16 treatment. Potassium and $\mathrm{Mg}^{2+}$ were higher in treatment 8 8-16. The relative increases of $\mathrm{Ca}^{2+}, \mathrm{Mg}^{2+}$ and $\mathrm{K}^{+}$in both fertilized treatments were in agreement with their respective contributions (more $\mathrm{K}^{+}$and $\mathrm{Mg}^{2+}$ in $8-8-16$, more $\mathrm{Ca}^{2+}$ in 11-18-11). After a water flow equivalent to 13 years of rainfall, and despite leaching losses, particularly of $\mathrm{K}^{+}$, both

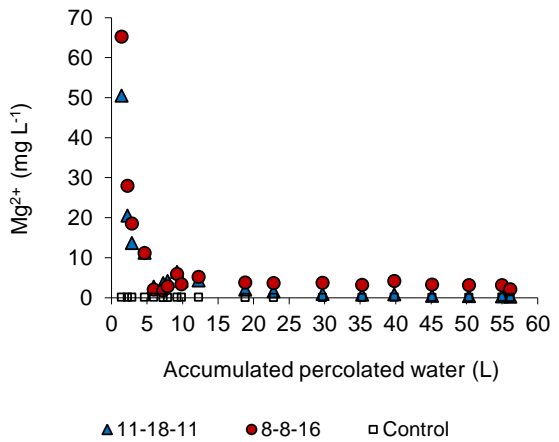

b)

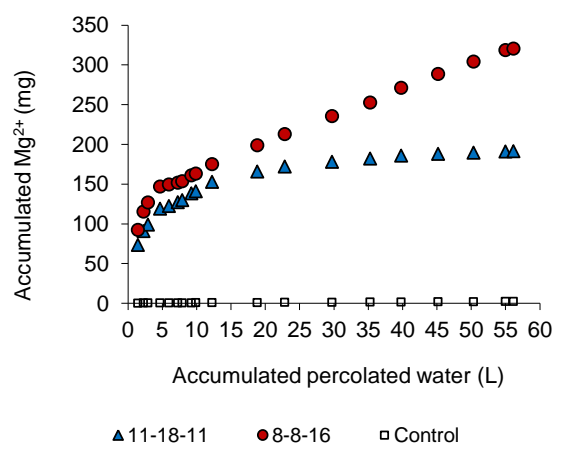

Figure 8. Magnesium concentrations in leachates (a) and accumulated $\mathrm{Mg}^{+2}$ losses (b) from fertilized and control columns along the experiment (average of three replicates).

fertilized soils were significantly enriched in these exchangeable cations. The remarkable decline of $\mathrm{Al}^{3+}$ in both fertilized treatments, compared to the control columns, is related to the $\mathrm{pH}$ increase (Table 3 ) and the input of other cations with fertilizers.

The eCEC was very low in control soils, in accordance with the low values corresponding to the initial soil (Table 1). In fertilized columns, the soil eCEC at the final stage had significantly increased (Table 3 ), being moderately low (between 4 and $9 \mathrm{cmol}(+) \mathrm{kg}^{-1}$ ), according to Buol et al. (1975). The increase of eCEC is related to the $\mathrm{pH}$ increase, given the variable-charge nature of the soils used in the experiment.

\subsection{Nutrient balances during the experiment}

The percentages of elements released from the tablets were calculated from the nutrient amounts contained initially in the fertilizer tablets and the amounts remaining at the end of the experiment (Table 4). Similarly, the percentages of leaching losses were calculated by comparing the accumulated leaching losses with the total amount of elements released from the tablets. Table 4 also shows the differences between the amounts released and leached for each element. 
Table 4. Quantity and percentages of elements released $(R)$ and leached $(L)$ from the tablets at the end of the experiment (average values of three replicates, with standard deviation in parentheses).

\begin{tabular}{|c|c|c|c|c|c|c|}
\hline Treatment & & $\mathrm{N}$ & $\mathrm{P}$ & $\mathrm{K}^{+}$ & $\mathrm{Ca}^{+2}$ & $\mathrm{Mg}^{+2}$ \\
\hline \multicolumn{7}{|l|}{$11-18-11$} \\
\hline \multirow[t]{4}{*}{ Released $(R)$} & $\mathrm{g}$ & 5.28 & 2.18 & 2.46 & 1.15 & 0.24 \\
\hline & & $(0.20)$ & $(0.18)$ & $(0.12)$ & $(0.40)$ & $(0.04)$ \\
\hline & $\%$ & 99.87 & 81.09 & 98.57 & 64.30 & 82.70 \\
\hline & & $(0.02)$ & $(2.50)$ & $(0.14)$ & (11.70) & (1.54) \\
\hline \multirow[t]{4}{*}{ Leached $(L)$} & $\mathrm{g}$ & 0.40 & 0.92 & 1.76 & 0.90 & 0.19 \\
\hline & & $(0.01)$ & (0.09) & $(0.16)$ & $(0.10)$ & $(0.01)$ \\
\hline & $\%$ & 7.62 & 34.32 & 70.40 & 50.77 & 64.25 \\
\hline & & $(0.42)$ & (3.32) & $(8.24)$ & $(10.7)$ & (3.03) \\
\hline \multirow[t]{2}{*}{$R-L$} & $\mathrm{~g}$ & 4.88 & 1.27 & 0.69 & 0.22 & 0.05 \\
\hline & & $(0.21)$ & $(0.14)$ & $(0.20)$ & $(0.09)$ & $(0.01)$ \\
\hline \multirow[t]{2}{*}{$\Delta$ soil } & $\mathrm{g}$ & 0.01 & 0.09 & 0.07 & 0.95 & 0.02 \\
\hline & & $(0.00)$ & $(0.02)$ & $(0.01)$ & $(0.11)$ & $(0.00)$ \\
\hline \multicolumn{7}{|l|}{$8-8-16$} \\
\hline \multirow[t]{4}{*}{ Released $(R)$} & g & 5.03 & 0.63 & 4.44 & 0.23 & 1.70 \\
\hline & & $(0.42)$ & $(0.10)$ & $(0.05)$ & $(0.08)$ & $(0.13)$ \\
\hline & $\%$ & 99.78 & 36.20 & 98.95 & 18.51 & 58.37 \\
\hline & & $(0.03)$ & $(4.05)$ & $(0.17)$ & $(5.51)$ & $(2.72)$ \\
\hline \multirow[t]{4}{*}{ Leached $(L)$} & $\mathrm{g}$ & 0.45 & 0.30 & 2.80 & 0.05 & 0.31 \\
\hline & & $(0.02)$ & $(0.04)$ & (0.09) & $(0.01)$ & $(0.05)$ \\
\hline & $\%$ & 8.86 & 17.25 & 63.80 & 4.09 & 10.80 \\
\hline & & $(0.39)$ & $(1.52)$ & $(2.63)$ & $(0.71)$ & $(1.41)$ \\
\hline \multirow[t]{2}{*}{$R-L$} & $\mathrm{~g}$ & 4.58 & 0.33 & 1.57 & 0.18 & 1.37 \\
\hline & & $(0.41)$ & $(0.05)$ & $(0.10)$ & $(0.08)$ & $(0.08)$ \\
\hline \multirow[t]{2}{*}{$\Delta$ soil } & $\mathrm{g}$ & 0.01 & 0.06 & 0.32 & 0.29 & 0.46 \\
\hline & & $(0.03)$ & $(0.01)$ & $(0.07)$ & $(0.02)$ & $(0.05)$ \\
\hline
\end{tabular}

Leached: accumulated leaching loss referred to the initial amount in the tablet. $R-L$ : difference between the amount released from the tablet and the amount leached. $\Delta$ soil: increase of the amount of $\mathrm{N}\left(\mathrm{N}-\mathrm{NO}_{3}-+\mathrm{NH}_{4}+\right)$, available $\mathrm{P}$ and exchangeable cations in the fertilized soil columns

The results were compared with the increase in the amounts of $\mathrm{N}$ (ammonium and nitrate), available $\mathrm{P}$ and exchangeable cations, calculated as the difference between data from fertilized and control columns (Table 4). In general, the percentages of elements released at the end of the trial were very high, except for $\mathrm{P}, \mathrm{Ca}^{2+}$ and $\mathrm{Mg}^{2+}$ from tablet 8-8-16. With regard to leaching, it was remarkable the extremely low percentage of $\mathrm{N}$ leached (<9\%) (Table 4). When comparing the differences between released and leached $\mathrm{N}(R-L)$ with the increase experienced by the forms of available $\mathrm{N}$ in the columns ( $\Delta$ soil), it is evident that a very low proportion of the $\mathrm{N}$ released from tablets to soil was as ammonium and nitrate. The nitrogen released by the tablets may be retained by soil in different ways: immobilized in microbial biomass or fixed in the interlayers of certain 2:1 clay minerals (Micks et al., 2004; Nieder et al., 2011). Part of the nitrogen may be lost from soil, either by leaching or through de-nitrification processes. De-nitrification is expected to play an important role in the reducing conditions prevailing during the experiment. This process, as well as microbial immobilization of $\mathrm{N}$ and $\mathrm{NH}_{4}^{+}$retention in clays, can help explain the results obtained. Also Paramasivam and Alva (1997) reported low recovery of the applied $\mathrm{N}$ in the leachate (from 5 to $28 \%$ ) in experiments with different ureabased controlled-release formulations (Meister, Osmocote, and Poly-S) added to soil columns, attributing it to the combination of loss of $\mathrm{N}$ through $\mathrm{NH}_{3}$ volatilization, microbial assimilation of the applied $\mathrm{N}$ and de-nitrification processes. Phosphorus was leached at low rates (Table 4), as expected from its well-known low mobility and in agreement with the increases in soil available P. Differences between $R-L$ and $\Delta$ soil with regard to available $\mathrm{P}$ can be due to $\mathrm{P}$ retention in soil in non-available forms, as well as to $\mathrm{P}$ immobilization in bacteria along the experiment. By contrast, $\mathrm{K}^{+}$leaching was relatively high (more than $60 \%$ of the total present in the tablet). The $\mathrm{K}^{+}$not leached can remain in the soil either as exchange cation or fixed by hydroxy-aluminum vermiculites that are very common in these granitic acidic soils, and due to that fixation a fraction of $\mathrm{K}^{+}$can be as unchangeable, causing that $\Delta$ soil is lower for $\mathrm{K}^{+}$than expected in view of $R-L$ data. Núñez-Delgado et al. (1997) also reported a nearly total $\mathrm{P}$ retention in soil and low $\mathrm{NH}_{4}^{+}$and $\mathrm{K}^{+}$leaching in column experiments carried out with Galician soils after the addition of cattle slurry. In another study also using laboratory columns and different CRF, but with a lower total water volume (21 L), Broschat and Moore (2007) obtained a P leaching between 47 and $80 \%$, lower than that of $\mathrm{N}$ and $\mathrm{K}^{+}(>80 \%)$. These percentages are clearly higher than those found in our study, probably because Broschat and Moore (2007) filled up their columns with washed sand, which had a much lower retention capacity for elements and compounds. Calcium and $\mathrm{Mg}^{2+}$ leaching, similarly to $\mathrm{Ca}^{2+}$ and $\mathrm{Mg}^{2+}$ release, were relatively high in treatment $11-18-$ 11 and low in treatment 8-8-16 (Table 4). Contrary to what happened to $\mathrm{NH}_{4}^{+}, \mathrm{K}^{+}$and $\mathrm{P}, \mathrm{Ca}^{2+}$ and $\mathrm{Mg}^{2+}$ showed low retention on soils, which could explain the divergences between $R-L$ and $\Delta$ soil affecting both cations. Magnesium corresponding to the 11-18-11 treatment was the element showing the lowest discrepancies among all those studied, with an increase of $0.02 \mathrm{~g}$ for exchangeable $\mathrm{Mg}^{2+}$ and a contribution of $0.05 \mathrm{~g}$ from the tablet. In contrast to what happened to the other elements, $\Delta$ soil was slightly higher than $R-L$ for exchangeable $\mathrm{Ca}^{2+}$, which could be due to the conversion from un-available to exchangeable affecting some forms of Ca during the percolation experiment. This anomalous behavior is in accordance with the particular evolution of leached $\mathrm{Ca}^{2+}$ (Fig. 7), showing an initial decrease, then further losses of $\mathrm{Ca}^{2+}$ maintained till the end of the experiment.

\section{Conclusions}

At the end of the trial, after the percolation of an amount of water equivalent to 13 years of rainfall in the area, releases from fertilizer tablets were more than $80 \%$ for most 
elements. Under the conditions of this study, $\mathrm{Ca}^{2+}$ and $\mathrm{Mg}^{2+}$ were usually released at lower rates, especially in the treatment $8-8-16$ (less than $60 \%$ ), while more than $99 \%$ of $\mathrm{N}$ was released from both tablets. Despite this, the amounts leached were generally low when compared with the total released. Most leaching occurred at the beginning of the experiment, within an interval of flow equivalent to 1.5 years of rainfall. From that moment on, an increase of $\mathrm{pH}$ and a sharp decrease of nutrient concentrations were observed in leachates. The overall results indicate that most of the elements contained in the fertilizers were leached in low percentage, referring to the total amounts present in the tablets, especially in the case of the 8-8-16 treatment. At the end of the percolating study, the concentrations of available $\mathrm{Ca}^{2+}$, $\mathrm{Mg}^{2+}, \mathrm{K}^{+}$and $\mathrm{P}$ had increased significantly in the soils into the fertilized columns, along with $\mathrm{pH}$ and effective CEC, showing at the same time a decrease of exchangeable $\mathrm{Al}^{3+}$. This means that, under the conditions of this study, the fertilizer treatments maintained their effects in these soils even after the passage of a water flow equivalent to 13-year rainfall. In these conditions, the formulation 8-8-16 underwent a lower overall nutrient loss that would be more suitable for crops having a nutrient demand sustained over time, also implying lower risks of water pollution, while the formulation 11-18-11 would be more suitable for crops with a strong initial demand.

Acknowledgements. The authors thank Fertiarbol S. L. for providing fertilizer tablets. We also thank the work of the editors and anonymous reviewers that greatly improved the initial manuscript.

Edited by: P. Pereira

\section{References}

Alva, A. K.: Sustainable nutrient management in sandy soils - Fate and transport of nutrients from animal manure versus inorganic sources, J. Sustain. Agr., 28, 139-155, 2006.

Bará, S. and Morales, F.: Suministro lento de nutrientes con fertilizantes pastillados para uso forestal, Estudio lisimétrico de las pastillas y resultados de las experiencias de fertilización, Anales del Instituto Nacional de Investigaciones Agrarias, Serie Recursos Naturales, 3, 235-249, 1977.

Bremner, J. M.: Inorganic forms of nitrogen, in: Methods of Soil Analyses, Part 2, Chemical and Microbiological Soil Properties, edited by: Black, C. A., Evans, D. D. ; Ensminger, L. E., White, J. L., and Clark, F. E., American Society of Agronomy, Madison, Wisc. USA, Agronomy N, 9, 1179-1237, 1965.

Broschat, T. K. and Moore, K. K.: Release Rates of AmmoniumNitrogen, Nitrate-Nitrogen, Phosphorus, Potassium, Magnesium, Iron, and Manganese from Seven Controlled-Release Fertilizers, Commun. Soil Sci. Plan. 38, 843-850, 2007.

Buol, S. W., Sánchez, P. Q., Cate, R. B., and Granger, M. A.: Soil fertility capability classification for fertility management, in: Soil Management in Tropical America, edited by: Bornemisza, E. and
Alvarado, A., North Carolina State Univ., Raleigh, NC, USA, 126-145, 1975.

Chen, D., Suter, H. C., Islam, A., Edis, R., and Freney, J. R.: Prospects of improving efficiency of fertilizer nitrogen in Australian agriculture: a review of enhanced efficiency fertilizers, Aust. J. Soil Res. 46, 289-301, 2008.

Cheng, W. G., Sudo, S., Tsuruta, H., Yagi, K., and Hartley, A.: Temporal and spatial variations in $\mathrm{N}_{2} \mathrm{O}$ emissions from a Chinese cabbage field as a function of type of fertilizer and application, Nutr. Cycl. Agroecosys. 74, 147-155, 2006.

Entry, J. A. and Sojka, R. E.: Matrix based fertilizers reduce nitrogen and phosphorus leaching in three soils, J. Environ. Manage., 87, 364-372, 2008.

García-Rodeja, I. and Gil-Sotres, F.: Prediction of parameters describing phosphorus-desorption kinetics in soils of Galicia (Northwest Spain), J. Environ. Qual. 26, 1363-1369, 1997.

Gil-Sotres, F. and Diaz-Fierros, F.: Phosphorus in forest soils of Sierra del Barbanza (Galicia, Spain). 2: Phosphorus retention study, Agrochimica 26, 213-221, 1982.

Hangs, R. D., Knight, J. D., and Van-Rees, K. C. J.: Nitrogen Accumulation by Conifer Seedlings and Competitor Species from 15Nitrogen-labeled Controlled-Release Fertilizer, Soil Sci. Soc. Am. J., 67, 300-308, 2003.

Hyatt, C. R., Venterea, R. T., Rosen, C. J., Mcnearney, M., Wilson, M. L., and Dolan, M.S.: Polymer-Coated Urea Maintains Potato Yields and Reduces Nitrous Oxide Emissions in a Minnesota Loamy Sand, Soil Sci. Soc. Am. J., 74, 419-428, 2010.

IUSS-WRB: World Reference Base for Soil Resources: World Soil Resources Reports, No. 103, FAO, Rome, Italy, 2007.

Jingyan, J., Zhenghua, H., Wenjuan, S., and Yao, H.: Nitrous oxide emissions from Chinese cropland fertilized with a range of slowrelease nitrogen compounds, Agr. Ecosyst. Environ., 135, 216225, 2010.

Jiménez-Gomez, S.: Fertilizantes de liberación lenta, MundiPrensa, Madrid, Spain, 1992.

Khan, F. A., Naushin, F., Rehman, F., Masoodi, A., Irfan, M., Hashmi, F., and Ansari, A. A.: Eutrophication: Global Scenario and Local Threat to Dynamics of Aquatic Ecosystems, in: Eutrophication: Causes, Consequences and Control, edited by: Ansari, A. A. and Gill, S. S., Springer, Dordrecht, The Netherlands, 17-27, 2014.

Keeney, D. R. and Nelson, D. W.: Nitrogen: inorganic forms, in: Methods of soil analysis, Part. 2, Chemical and Microbiological Properties 2nd edn, SSA, Madison, Wisconsin, USA, 643-698, 1982.

Micks, P., Aber, J. D., Boone , R. D. and Davidson, E. A.: Shortterm soil respiration and nitrogen immobilization response to nitrogen applications in control and nitrogen-enriched temperate forests, For. Ecol. Manage., 196, 57-70, 2004.

Nieder, R., Benbi, D. K., and Scherer, H. W.: Fixation and defixation of ammonium in soils: a review, Biol. Fertil. Soils, 47, 1-14, 2011.

Núñez-Delgado, A., López-Periago, E., and Díaz-Fierros, F.: Breakthrough of inorganic ions present in cattle slurry: soil columns trials, Water Res., 31, 2892-2898, 1997.

Núñez-Delgado, A., López-Periago, E., and Díaz-Fierros, F.: Pollution attenuation by soils receiving cattle slurry after passage of a slurry-like feed solution, Column experiments, Bioresource Technol., 84, 229-236, 2002. 
Oertli, J. J.: Controlled-release fertilizers, Fert. Res., 1, 103-123, 1980.

Olsen, S. R. and Sommers, R. E.: Phosphorus, in: Methods of Soil Analysis. Part. 2, Chemical and Microbiological Properties, 2nd edn. SSA, Madison, Wisconsin, USA, 403-430, 1982.

Paramasivam, S. and Alva, A. K.: Leaching of nitrogen forms from controlled-release nitrogen fertilizers, Commun. Soil Sci. Plan., 28, 1663-1674, 1997.

Peech, L., Alexander, L. T., and Dean, L. A. Methods of Analysis for Soil Fertility Investigations, 1947.

Pousada-Ferradás, Y., Seoane-Labandeira, S., Mora-Gutiérrez, A., and Núñez-Delgado, A.: Risk of water pollution due to ashsludge mistures: column trials, Int. J. Environ. Sci. Te., 9, 1-29, 2012.
Shaviv, A.: Advance in Controlled-Release Fertilizers, Adv. Agron., 71, 1-49, 2001.

Sato, S. and Morgan, K. T.: Nitrogen Recovery and Transformation from a Surface or Sub-Surface Application of ControlledRelease Fertilizer on a Sandy Soil, J. Plant Nutr., 31, 2214-2231, 2008.

Shoji, S. and Kanno, H.: Use of polyolefin-coated fertilizers for increasing fertilizer efficiency and reducing nitrate leaching and nitrous oxide emissions, Fert. Res., 39, 147-152, 1994.

Wilson, M. L., Rosen, C. J., and Moncrief, J. F.: Effects of Polymercoated Urea on Nitrate Leaching and Nitrogen Uptake by Potato, J. Environ. Qual., 39, 492-499, 2010.

Xiong, Z. Q., Huang, T. Q., Ma, Y. C., Xing, G. X., and Zhu, Z. L.: Nitrate and Ammonium Leaching in Variable- and PermanentCharge Paddy Soils, Pedosphere, 20, 209-216, 2010. 